\title{
Growth of immature Chironomus calligraphus (Diptera, Chironomidae) in laboratory conditions
}

\author{
RITA DE CÁSSIA S.A. CANTEIRO ${ }^{1}$ and EDÉlti F. ALBERTONI ${ }^{2}$ \\ ${ }^{1}$ Pós-Graduação em Biologia de Ambientes Aquáticos Continentais, Laboratório de Limnologia, \\ Universidade Federal de Rio Grande (FURG), Caixa Postal 474, 96201-900 Rio Grande, RS, Brasil \\ ${ }^{2}$ Instituto de Ciências Biológicas, Laboratório de Limnologia, Universidade Federal de Rio Grande (FURG), \\ Caixa Postal 474, 96201-900 Rio Grande, RS, Brasil \\ Manuscript received on September 2, 2010; accepted for publication on February 4, 2011
}

\begin{abstract}
Chironomidae larvae are important macroinvertebrates in limnic environments, but little knowledge exists about their biometrics development characteristics. This study aims to describe the immature Chironomus calligraphus Goeldi, 1905 under laboratory conditions by the accomplishment of thirteen egg masses from eggs eclosion to adults emergency, at controlled room temperature $\left(25^{\circ} \mathrm{C}\right)$ and photoperiod $(12-12 \mathrm{~h})$. Larvae were feed ad libitum with "Alcon Basic - MEP 200 Complex" fish food and commercial dehydrated Spirulina. The postures had a mean length of $9 \pm 1 \mathrm{~mm}(\mathrm{n}=13)$ and $348 \pm 66$ eggs. The brownish colored eggs with elliptical shape had length of $160.3 \pm 17.7 \mu \mathrm{m}$ $(n=130)$, being arranged as an organized string in a pseudo spiral form. The time duration from the first to the four instars were three, four, four and eight days, and the average length of a cephalic capsule to each one of the instars $(66.3 \pm 12.3 \mu \mathrm{m}, 102.9 \pm 22.1 \mu \mathrm{m}, 159 \pm 24.6 \mu \mathrm{m}, 249.2 \pm 29.7 \mu \mathrm{m}, \mathrm{n}=456)$ were significantly different (ANOVA, $\mathrm{p}<0.001)$. The Dyar's Rule showed a constant growth rate, $r=1.5$. Our results demonstrated that $C$. calligraphus is a species with short life cycle, low mortality rate, food adaptability, fast larval growth and easily maintained at laboratory, factors that allowed the use of this native species as a tool for ecotoxicological tests.
\end{abstract}

Key words: aquatic insects, laboratory development, larval instars, life cycle.

\section{INTRODUCTION}

Chironomidae larvae are the most abundant macroinvertebrates group in limnic environments, occurring as larvae in high density and diversity in most types of freshwater ecosystems (Epler 1992, Trivinho-Strixino and Strixino 1995, Coffman and Ferrington Jr 1996, Osborne et al. 2000, Takeda et al. 2001, Brito Jr et al. 2005). The variability of environmental conditions under which chironomids are found is more extensive than for any other group of aquatic insects (Merritt et al. 2008). The ecological amplitude is related to several morphological, physiological and behavioral ad-

Correspondence to: Edélti Faria Albertoni E-mail: dmbefa@furg.br aptations found among the members of this family (Coffman and Ferrington Jr 1996). Such adaptations may explain the wide spread of the group, as observed and registered worldwide (Ferrington Jr 2008).

According to MacDonald and Taylor (2006) and Armitage et al. (1995), Chironomidae go through three ecdyses during the larval development: in transitions from the first to the second instar, from the second to the third instar, and from the third to the fourth instar. Time of different instars varies from one species to another, with fourth instars often being longer than earlier instars (Tokeshi 1995). The pupal stage is relatively short; at this point larvae molt into the adult form, when pupa leaves exuviae on the water surface and the 
adult emerges. Adult males usually form flocks to attract females (Porinchu and MacDonald 2003).

Due to the high taxonomic complexity of this family, the identification of many species is only possible with a correct association of larval, pupal and adult stages (Trivinho-Strixino and Strixino 1995). The knowledge of life cycle patterns as emergence phenology and voltinism is important for a better understanding on the biology and ecology of the family, and may also contribute to bioassays in toxicity studies (Corbi and Trivinho-Strixino 2006). Some studies were carried out about life cycles and development of Chironomidae in Brazil, for examples Trivinho-Strixino and Strixino (1982, 1989, 1995), Strixino and TrivinhoStrixino (1985), Corbi and Trivinho-Strixino (2006).

The genus Chironomus Meigen, 1803 is worldwide distributed and can be found in lotic and lentic environments, usually in organically enriched water (Marques et al. 1999). The identification of Chironomus species is difficult because many of them cannot be separate by larval external morphology, and the adults show great intraspecific variation of morphological characters (Correia et al. 2005). The separation of species requires an analysis of the characteristics of all life stages together with cytotaxonomic analysis using polytene chromosomes (Correia et al. 2005).

Chironomus calligraphus Goeldi, 1905 is a PanAmerican chironomid with predominantly Neotropical distribution (Spies et al. 2002, Zilli et al. 2008). According to Iannacone and Salazar (2007), C. calligraphus is typical from natural environments and domestic treated wastewater in Peru, and was cited for Colombia and Southern United States of America (Spies et al. 2002). Zilli et al. (2008) described the life cycle of this species collected in field waters of Argentina. According to Correia and Trivinho-Strixino (2005), this species was sampled in north, middle-west and southeastern Brazil. No record for $C$. calligraphus had been made in south Brazil. Iannacone and Salazar (2007) considered it suitable for ecotoxicological assay and evaluation of different types of water quality. Ferrington $\mathrm{Jr}$ (2008) pointed out that one of the world areas with great number of undescribed species is Brazilian lowlands. Thus this study tries to contribute for the improvement of the geographical distribution and biological knowledge of C. calligraphus.
This study was carried out in order to describe some biological characteristics of the immature $C$. calligraphus like egg size and number, time of each larval development stage and time to adult emergency in laboratory.

\section{MATERIALS AND METHODS}

Thirteen egg masses of $C$. calligraphus were collected from a domestic pool in the Cassino Beach, Rio Grande, RS, Brazil $\left(32^{\circ} 10^{\prime} 57^{\prime \prime} \mathrm{S} / 52^{\circ} 10^{\prime} 24^{\prime \prime} \mathrm{O}\right)$, in November, 2007. Postures were adhered to plant debris, which formed large masses.

In the laboratory, egg masses were transferred to Petri dishes containing water and photographed under a stereomicroscope with a MOTIC CAM ${ }^{\circledR}$ camera and its software. Lengths of ten eggs of each egg mass were measured. Subsequently, the masses were placed individually in plastic trays $(27 \mathrm{~cm} \times 18 \mathrm{~cm} \times 6 \mathrm{~cm})$ with permanently oxygenated water $(1.5 \mathrm{~L})$, at controlled room temperature $\left(25^{\circ} \mathrm{C}\right)$ and photoperiod $(12 / 12 \mathrm{~h})$. The trays were covered with screens to retain and collect adults.

After the eclosion of eggs and the dispersion of emergent larvae, they were fed with the fish feed "Alcon Basic - MEP 200 Complex" and dried commercial Spirulina, ad libitum.

Three larvae were removed from each tray and photographed daily. Length of the ventral cephalic capsule $(\mu \mathrm{m})$ and total body length $(\mu \mathrm{m})$ were measured under a stereomicroscope to obtain the growth curves, relative (cephalic capsule versus body length), and through time (body length versus time of development) of the species, through single dispersion graphics, which gathered all the measured postures. The width $(\mu \mathrm{m})$ of cephalic capsules was obtained by applying the Dyar's Rule (Dyar and Rhinebeck 1890) to determine the growth ratio of each larval instar. Some larvae and adults (males and females) of $C$. calligraphus were fixed in $80 \%$ alcohol and deposited in the Collection of Subtropical Limnic Invertebrates (Federal University of Rio Grande - FURG).

The mean length of the head capsule in each instar was obtained by the graphic method described by Corbi and Trivinho-Strixino (2006), which establishes a relationship between head length and total body length. The mean length values of cephalic capsules and total body length of each instar were compared by one way ANOVA with Tukey Post Test. 


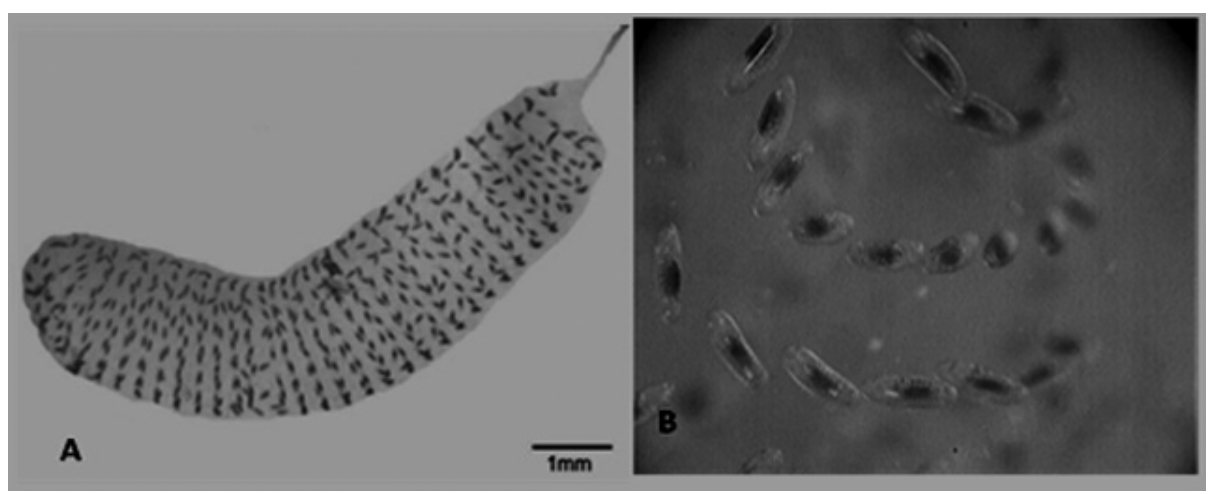

Fig. 1 - (A) Egg masses of Chironomus calligraphus Goeldi, 1905. (B) Detail of eggs loops.

\section{RESULTS}

The collected postures had a gelatinous matrix of cylindrical aspect, and consisted of an egg string radially arranged and organized into a pseudo spiral form. As the egg string turned within the innermost part of the gelatinous mass, it resulted in a false spiral aspect (Figs. $1 \mathrm{~A}$ and $1 \mathrm{~B})$.

The postures had a mean length of $9 \pm 1 \mathrm{~mm}$ and a mean egg amount of $348 \pm 66(n=13)$. The eggs were brownish colored and with an elliptical shape and a mean length of $160.3 \pm 17.7 \mu \mathrm{m}(\mathrm{n}=130)$.

The emergent larvae had a mean length of $792 \pm$ $128 \mu \mathrm{m}(\mathrm{n}=39)$. Still colorless, they left the gelatinous part that involves the eggs and started to actively swim and scattered themselves. One of the postures had high larval mortality rate and was disregarded of the growth analysis.

Chironomus calligraphus relative growth curve built with ventral cephalic capsule length and body length $(\mu \mathrm{m})$ indicates a logarithmic tendency with high determination coefficient $\left(\mathrm{R}^{2}=0,81\right)$, and it had the following equation as general model: $\mathrm{BL}=96.618$ $\mathrm{Ln}(\mathrm{CCL})-576.94$, where $\mathrm{BL}=$ body length $(\mu \mathrm{m})$ and $\mathrm{CCL}=$ cephalic capsule length $(\mu \mathrm{m})$. The values were observed throughout the larval development stage from the emergence of larvae to the emergence of adult individuals $(n=456)$ (Fig. 2). The growth curve of immatures through time (data log transformed) had a high determination coefficient $(\mathrm{LOG}(\mathrm{BL})=0.076 \mathrm{t}+2.791$, where BL is body length $(\mu \mathrm{m})$ and $\mathrm{t}=$ time in days; $\mathrm{R}^{2}$ $=0.96)$ and presented a relative constant body length at final days of larval growth (Fig. 3).
Four larval instars were separated, and differences concerning their time were found, as well as the mean ventral width of cephalic capsules (Table I) (Fig. 4). The mean ventral length of the cephalic capsules also had a significant difference $(\mathrm{F}=1288.4, \mathrm{p}<0.001)$ : all instars were different from each other, which confirmed the method used to identify the larval development instars of the species. Total body length among instars was significantly different $(\mathrm{F}=254.52, \mathrm{p}<0.0001)$. The application of Dyar's Rule showed constant a growth ratio, $r=1.5$, among instars.

The first adult emergence of each posture ranged between the $9^{\text {th }}$ and the $11^{\text {th }}$ day $(10 \pm 1$ day, $\mathrm{n}=12)$ in this study. Such variation characterized the period between the egg emergence and the adulthood of species. After the fourth instar, larvae turned on short pupal instar and adults emergency occurred quickly, in 24 hours or less.

\section{DISCUSSION}

The egg masses of Chironomidae are composed by a gelatinous matrix to protect the eggs, which are hydrated when in contact with water, resulting in a posture of morphological aspect that is typical of some groups. The Chironomini tribe has globular and/or cylindrical egg masses formed by an egg string of different form, with central fibers that consist of a filament pair lengthened through the egg mass (Nolte 1993). The eggs shape of C. calligraphus is typically elliptical, according to Armitage et al. (1995), and the medium size of eggs followed the one of smaller species, around $170 \mu \mathrm{m}$. 


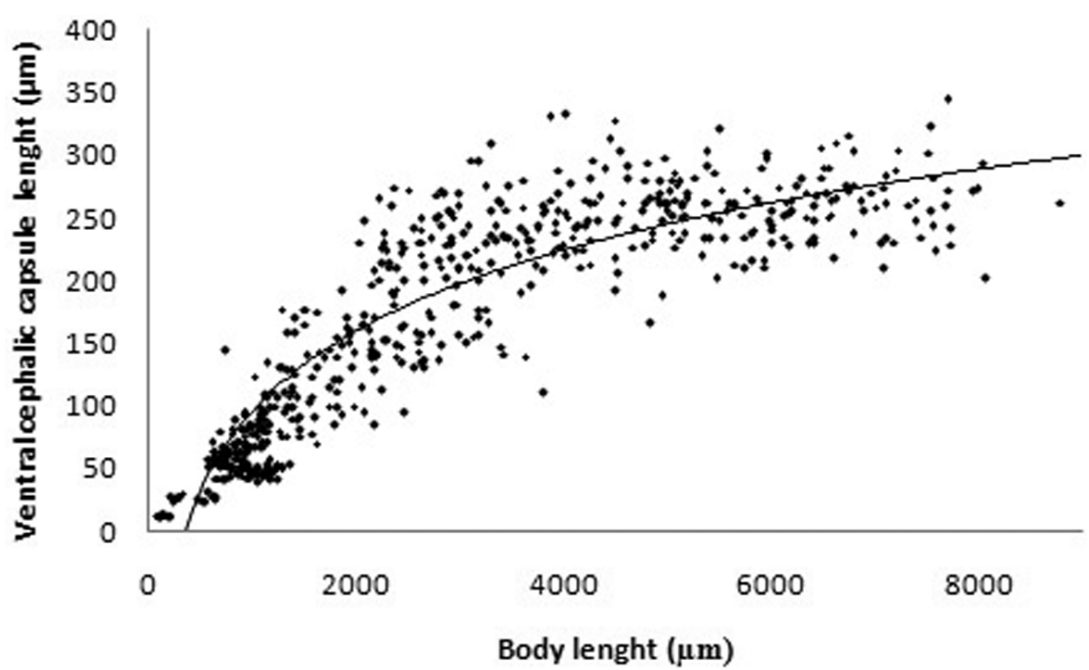

Fig. 2 - Relative growth curve of Chironomus calligraphus Goeldi, 1905 in laboratory conditions.

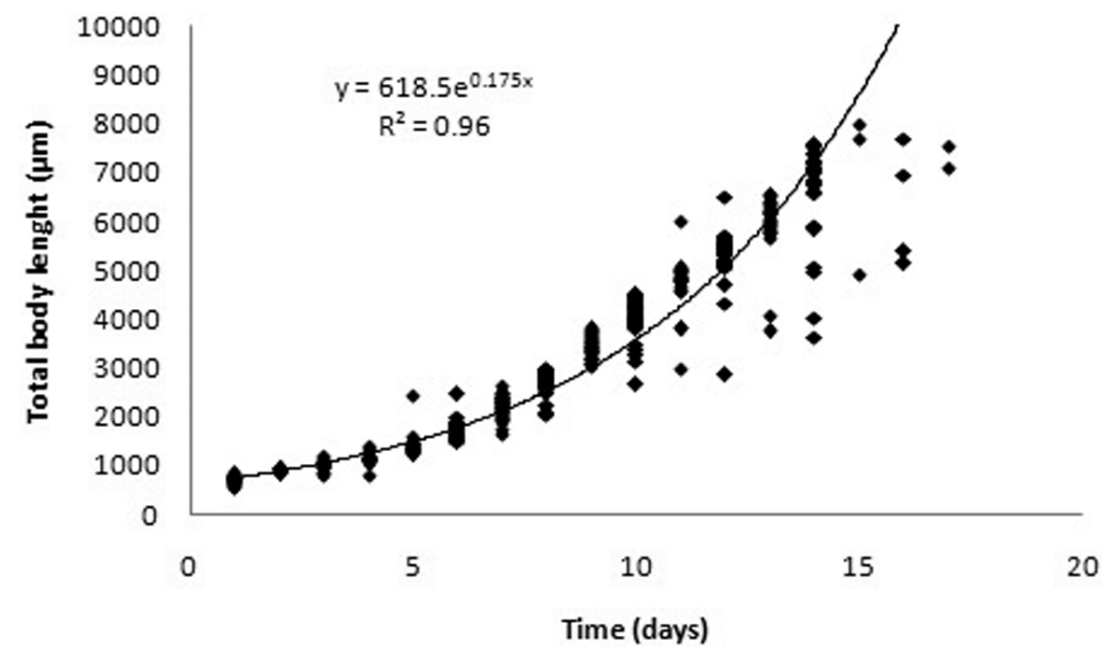

Fig. 3 - Growth curve of Chironomus calligraphus Goeldi, 1905.

TABLE I

Duration of larval development stages (in days), body length, cephalic capsule measurements and Dyar growth rate among instars of Chironomus calligraphus Goeldi, 1905.

\begin{tabular}{c|c|c|c|c|c|c}
\hline $\begin{array}{c}\text { Larval } \\
\text { instars }\end{array}$ & "n" & $\begin{array}{c}\text { Period } \\
\text { mean (SD) }\end{array}$ & $\begin{array}{c}\text { BL } \\
\text { mean (SD) }\end{array}$ & $\begin{array}{c}\text { CCW } \\
\text { mean (SD) }\end{array}$ & $\begin{array}{c}\text { CCL } \\
\text { mean (SD) }\end{array}$ & r \\
\hline I & 77 & $3(2)$ & $612.8(229.3)$ & $63.9(10.1)$ & $66.3(12.2)$ & 1.5 \\
II & 62 & $4(1)$ & $993.5(72.2)$ & $100.2(11.5)$ & $102.2(4.1)$ & 1.5 \\
III & 72 & $4(3)$ & $1324.6(160.6)$ & $161.8(17.0)$ & $159(24.6)$ & 1.5 \\
IV & 245 & $8(2)$ & $4258.1(1744.7)$ & $261.9(34.2)$ & $249.2(29.6)$ & 1.5 \\
\hline
\end{tabular}

$\mathrm{BL}=$ Body length $(\mu \mathrm{m}) ; \mathrm{CCW}=$ Ventral mean width of the cephalic capsule $(\mu \mathrm{m}) ; \mathrm{CCL}$ $=$ Ventral mean length of the cephalic capsule $(\mu \mathrm{m}) ; \mathrm{r}=$ Growth rate (Dyar's determination); Period $=$ Duration (days). 


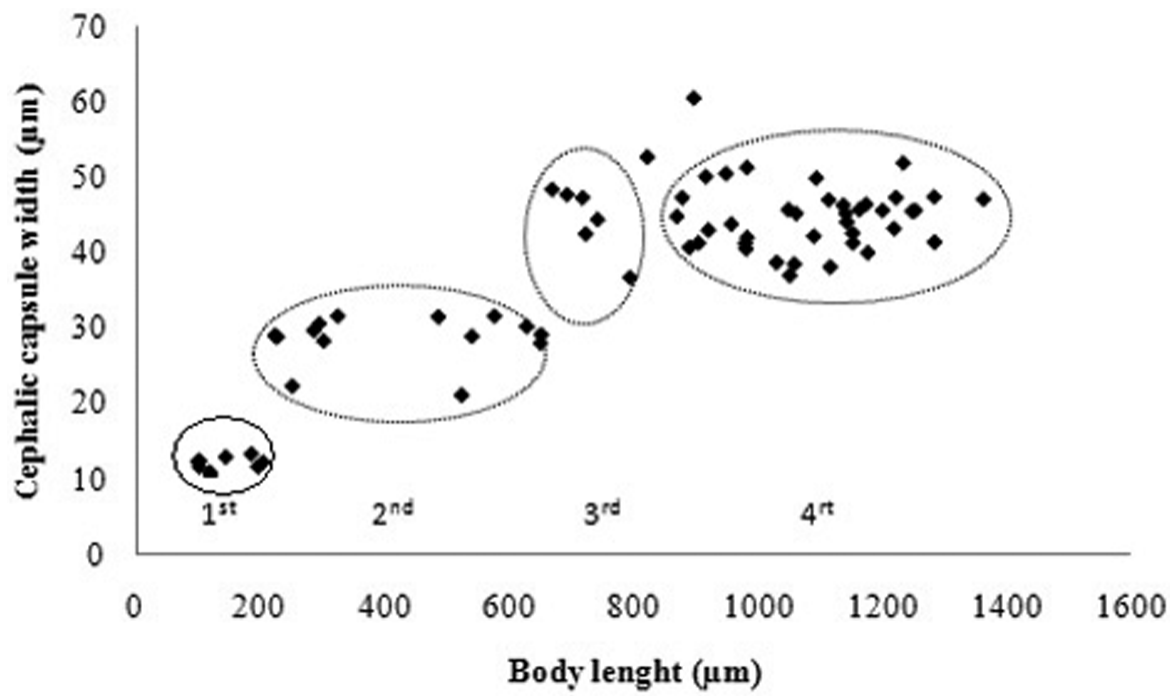

Fig. 4 - Relationship between head capsule width $(\mu \mathrm{m})$ and total body length $(\mu \mathrm{m})$ of Chironomus calligraphus Goeldi, 1905 larval instars.

According to Tokeshi (1995), the egg development of Chironomidae seems to happen in relatively short time, within a few days to one month, and to be positively related with temperature. As in egg development, temperature constitutes a major controlling factor in larval growth. Some studies have demonstrated that the growth rate of larvae is increased at higher temperatures (Menzie 1981, Ward and Cummins 1979, Fonseca and Rocha 2004). In this study, C. calligraphus grew at $25^{\circ} \mathrm{C}$, which is a temperature that allows a fast growth rate and the development until the imago phase. Our results showed that this species has few eggs when compared with other chironomids, as found by Corby and Trivinho-Strixino (2006) for two Goelchironomus species (780 and 600 eggs), Trivinho-Strixino and Strixino (1982) who registered 500 to 1045 eggs for $C$. xanthus, and Hooper et al. (2003) that reported 600 eggs for C. xanthus. For C. calligraphus in Argentina, Zilli et al. (2008) reported the number of eggs per mass ranged from 369 to 374 , similarly to our results.

According to Nolte (1993), intraspecific variations in egg amount are common in the Chironomidae family, and there may be a proportional relation between larval development time of the female ovipositor and the number of eggs in the posture. Consequently, a female of longer larval development may produce more eggs than that of shorter larval development.
The results of this study showed a higher average time for the fourth instar, which is considered normal for Chironomidae by Fonseca and Rocha (2004). According to Armitage et al. (1995), the higher time may be due to the energy needed for the aggregation of individuals prior to mating. This behavior of complex mating dances reaches its highest development in certain Diptera, particularly Tipulidae, Culicidae and Chironomidae. There are some controversies about food and feeding of adults, and Armitage et al. (1995) pointed out that a wide range of species had feeding; Hooper et al. (2003) cited that adults doesn't feed.

Corbi and Trivinho-Strixino (2006) described a method to determine instars through the measurement of total body length and length of cephalic capsules of two species of Goeldichironomus. In this study they evidenced highly significant differences among the average instars of the studied species, and showed the possible intervals of larval ecdyses. Zilli et al. (2008) obtained for C. calligraphus from Argentina, differences into instars according to the relationship between head capsule width and total body length. In our study, the same method of Corbi and Trivinho-Strixino (2006) was used for this species, and it was possible to see the instar differences. Our results showed a great intraspecific variation (Table I), probably due to the number of egg masses used. Both previously mentioned study 
do not made reference to the number of eggs/larvae measured and, thus, we believe that cephalic capsule length and width are reliable characteristics of the four instars in some species of Chironomidae.

Hutchinson et al. (1997) compared information on the application of Dyar's Rule and discussed the physiological limits for growth. For example, when arthropods molt, the new exoskeleton is formed inside the old one; growth relation would be limited by the extensibility of the new cuticle (Hutchinson et al. 1997). The authors concluded that, even though the limits influence the growth, the observed variations suggest that the relation is generally spontaneous. Considering the observed growth ratio, the results of the C. calligraphus experiment evidenced compliance with the application of Dyar's Rule. To the same species from Argentina, Zilli et al. (2008) found a highest ratio, $r=1.60 \pm 0.02$, in larvae development under laboratory conditions.

After the fourth larval instar, the organism turned into the pupal stage, becoming dark colored and presenting a very distinct cephalothorax, soon emerging as a terrestrial adult. In general, the pupal stage time is very brief and varies from a few hours to a few days (Oliver 1971). In our study, it was observed that the pupa moved onto the water surface when it was mature and the adult eclosion occurred quickly, as was pointed out by Pinder (1986). The emergence of the first adult varied from 9 to 12 days, but the time of development is very variable to Chironomidae. Regarding other species of Chironomidae, Goeldichironomus luridus had a time development of 20 days, and G. maculatus of 28 days, according to Corbi and Trivinho-Strixino (2006). C.A. Almeida (unpublished data) considered that the time of the larval stage of Chironomus xanthus under conditions of optimal temperature varies from 12 to 15 days. Zilli et al. (2008), in their study with C. calligraphus, found an average generation time of 23 days. This study, however, did not keep the temperature constant (ranging between 22.5 to $31^{\circ} \mathrm{C}$ ), and this factor could be important to the development time of Chironomidae, as pointed out Tokeshi (1995). To temperate species at its natural environment, this period could be more than a year (Carter 1980). Other factors that could allow a fast adult emergency are, according Hooper et al. (2003), food and physical space availability. Considering our laboratory conditions, larvae were fed $a d$ libitum and no competition for space was reported, since each posture grew in an individual tray.

The Chironomus calligraphus culture in laboratory was favored by the short period of egg incubation, low mortality rate, food adaptability and fast larval growth, as well as the easy obtainment of egg masses in field. With these results, under controlled laboratory conditions, C. calligraphus seems to be a species that invests in strategies for rapid development and production of new individuals, perhaps as a means of rapid occupation of habitats. Shallow aquatic ecosystems found in southern coastal plain of Rio Grande do Sul State may have ephemeral characteristics, being subject to drought in dry periods, that favors the species with rapid development and production of reproductive adults.

Intraespecific differences in the development stages are common for the Chironomidae family and ordinarily associated to the number of factors that influenced the larval development of the female. Corbi and TrivinhoStrixino (2006) stated that studies on the life cycle of Chironomidae are unusual in the Neotropical region and, according to them, this kind of research is important because of the relevant information about the bionomics of such family and population aspects. As demonstred by Iannacone et al. (2003), C. calligraphus is a species with a higher sensibility to heavy metals and some plant extracts with potential biocides effects (Iannacone and Pérez-Dávila 2008). The authors suggest the use of this species in tests of environmental assessment. According to the authors, the biological organisms to be employed as ecotoxicological tools should be easily maintained under laboratory conditions, sensitive and reproductible, and the results obtained in our research may contribute to future use of $C$. calligraphus in ecotoxicological tests.

\section{ACKNOWLEDGMENTS}

We thank Fundação de Amparo à Pesquisa do Estado do Rio Grande do Sul (case 619817) for the financial support, Dr. Leny Correia for the help in the identification, and Dr. Marcos Callisto, Dr. Gilberto Rodrigues and Dr. Humberto Mendes for the criticisms and suggestions during the study, and anonymous referees for improving the manuscript. 


\section{RESUMO}

Larvas de Chironomidae são importantes componentes em ambientes límnicos, mas pouca informação está disponível sobre as características biométricas em seu desenvolvimento. Este estudo objetivou descrever os imaturos de Chironomus calligraphus Goeldi, 1905 em condições de laboratório, através do acompanhamento de treze posturas da espécie desde a eclosão dos ovos até a emergência dos adultos, sob temperatura $\left(25^{\circ} \mathrm{C}\right)$ e fotoperíodo controlados $(12-12 \mathrm{~h})$. As larvas foram alimentadas com ração para peixes "Alcon Basic - MEP 200 Complex" e Spirulina comercial desidratada. A postura apresentou comprimento médio de $9 \pm 1 \mathrm{~mm}(\mathrm{n}=13)$ e $348 \pm 66$ ovos. Estes, de cor amarronzada e formato elíptico, apresentaram comprimento de 160,3 $\pm 17,7 \mu \mathrm{m}(\mathrm{n}=130)$, arranjados como uma fita em formato pseudo-espiralado. A duração do primeiro ao quarto estágio foi de três, quatro, quatro e oito dias, e os comprimentos médios da cápsula cefálica para cada um dos estágios $(66,3 \pm 12,3 \mu \mathrm{m}, 102,9 \pm$ $22,1 \mu \mathrm{m}, 159 \pm 24,6 \mu \mathrm{m}, 249,2 \pm 29,7 \mu \mathrm{m}, \mathrm{n}=456)$ foram significativamente diferentes (ANOVA, $\mathrm{p}<0,001$ ). A regra de Dyar mostrou taxa de crescimento constante, $r=1,5$. Nossos resultados demonstraram que C. calligraphus é uma espécie com ciclo de vida curto, baixa taxa de mortalidade, adaptabilidade de alimentação, rápido crescimento larval e facilmente mantida em condições de laboratório, fatores que permitem a utilização desta espécie nativa como ferramenta para testes ecotoxicológicos.

Palavras-chave: insetos aquáticos, desenvolvimento em laboratório, estágios larvais, ciclo de vida.

\section{REFERENCES}

Armitage PD, Cranston PS And Pinder LCV. 1995. The Chironomidae biology and ecology of non-biting midges, $1^{\text {st }}$ ed., London: Chapman \& Hall, 538 p.

Brito JR L, ABÍlio FJP AND WATANABE T. 2005. Insetos aquáticos do açude São José dos Cordeiros (semi-árido paraibano) com ênfase em Chironomidae. Entomol Vect 12(2): 149-157.

CARTER CE. 1980. The life cycle of Chironomus anthracinus in Lough Neagh Holar Ecol 3: 214-217.

CofFman WP AND FerRington JR LC. 1996. Chironomidae. In: MERRITt RW AND Cummins KW. 1996. An introduction to the aquatic insects of North America. Iowa: Kendall/Hunt, p. 635-755.
Corbi JJ AND TRIVINHO-STRIXINO S. 2006. Ciclo de vida de duas espécies de Goeldichironomus (Diptera, Chironomidae). Rev Bras Entomol 50(1): 72-75.

CORREIA LCS AND TRIVINHO-STRIXINO S. 2005. New records of Chironomus Meigen (Diptera, Chironomidae) in the State of São Paulo, Brazil. Rev Bras Entomol 49(3): 430-433.

CORREIA LCS, TRIVINHO-STRIXINO S AND MiCHAIlOVA P. 2005. A new species of Chironomus Meigen, 1803 (Diptera, Chironomidae) from the southeast of Brazil. Studies on the Neotropical Fauna and Environment 40(1): 29-38.

DyAR HG AND RHINEBECK NY. 1890. The number of molts of Lepidopterous larvae. Psyche 5: 420-422.

EPLER JH. 1992. Identification manual for the larval Chironomidae (Diptera) of Florida. Florida Department of Environmental Protection, p. 1-427.

FERRINGTON JR LC. 2008. Global diversity of non-biting midges (Chironomidae; Insecta-Diptera) in freshwater. Hydrobiologia 595: 447-455. Special Issue Freshwater Animal Diversity Assessment.

FonseCA AL AND RochA O. 2004. Laboratory cultures of the native species Chironomus xanthus Rempel, 1939 (Diptera, Chironomidae). Acta Limnol Brasil 16(2): 153-161.

Hooper HL, Sibly RM, Hutchinson TH AND MAUnd SJ. 2003. The influence of larval density, food availability and habitat longevity on the life history and population growth rate of the midge Chironomus riparius. Oikos 102: 515-524.

HutChinson JMC, MCNAMARA JM, Houston AIH AND Vollrath F. 1997. Dyars Rule and the investment principle: optimal moulting strategies if feeding rate is size-dependent and growth is discontinuous. Phil Trans R Soc Lond B 352: 113-138.

IANNACONE J AND PÉREZ-DÁvilA D. 2008. Efectos tóxicos de cuatro plantas amazónicas sobre Chironomus calligraphus Goeldi 1905 (Diptera: Chironomidae) y Artemia franciscana Kellog 1906 (Anostraca: Artemiidae). Rev Brasil Toxic 21(1): 25-32.

IANNACONE J AND SALAZAR N. 2007. Efecto Toxicológico de Muestras de Agua del Lago Junín, Perú, sobre Chironomus calligraphus (Diptera: Chironomidae). J Braz Soc Ecotoxicol 2(3): 219-227.

IANNACONE JA, SAlaZAR N AND Alvarino L. 2003. Variabilidad del Ensayo Ecotoxicológico con Chironomus calligraphus Goeldi (Diptera: Chironomidae) para evaluar Cadmio, Mercurio y Plomo. Ecol Apl 2(1): 103-110. 
MACDONALD EE AND TAYLOR BR. 2006. Incidence of mentum deformities in midge larvae (Diptera: Chironomidae) from Northern Nova Scotia, Canada. Hydrobiologia 563: $277-287$.

Marques MGSM, Barbosa FAR and Callisto M. 1999. Distribution and abundance of Chironomidae (Diptera, Insecta) in an impacted watershed in southeast Brazil. Rev Bras Biol 59(4): 553-561.

MenzIE CA. 1981. Production ecology of Cricotopus sylvestris (Fabricius) (Diptera, Chironomidae) in a shallow estuarine cove. Limnol Oceanogr 26: 467-481.

Merritt RW, Cummins KW And Berg MB. 2008. An Introduction to the Aquatic Insects of North America. $4^{\text {th }}$ ed., Dubuque, Kendall Hunt, p. 1-772.

Nolte U. 1993. Egg masses of Chironomidae (Diptera). A review including new observations and preliminary key. Entomologica Scandinavica, Supplement 43, p. 1-75.

Oliver DR. 1971. Life history of the Chironomidae. Annu Rev Entomol 16: 211-230.

Osborne S, Hurrel S, Simkiss K And Leidi A. 2000. Factors influencing the distribution and feeding of the larvae of Chironomus riparius. Entomol Exper App 94: $67-73$.

PINDER LCV. 1986. Biology of freshwater Chironomidae. Annu Rev Entomol 31: 1-23.

Porinchu DF And MacDonald GM. 2003. The use and application of freshwater midges (Chironomidae: Insecta: Diptera) in geographical research. Progress in Physical Geography 27: 378.

Spies M, Sublette Je, Sublette MF, Wülker WF, Martin J, Hille A, Miller MA And Witt K. 2002. Pan-American Chironomus calligraphus Goeldi, 1905 (Diptera, Chironomidae): Species or Complex? Evidence from External Morphology, Karyology and DNA Sequencing. Aquat Insec 24(2): 91-113.
StriXinO G AND TRIVINHO-STRIXINO S. 1985. A temperatura e o desenvolvimento larval de Chironomus sancticaroli (Diptera: Chironomidae). Rev Bras Zool 3: 177180

Takeda AM, Kobayashi JT, Resende D, Fujita DS, Avelino GS, Fujita RH, Pavan CB and ButakKa CM. 2001. A influência do decréscimo do nível fluviométrico na comunidade de Chironomidae da Planície Aluvial do Rio Paraná. Ed. UEM-NUPELIA, p. 1-100.

TOKEShI M. 1995. Life cycles and population dynamics In: ARMitage PD, CRANSTON PS AND PINDER LCV (Eds), The Chironomidae: Biology and Ecology of Non biting Midges. London: Chapman \& Hall, p. 225-250.

Trivinho-STRIXINO S And Strixino G. 1982. Ciclo de vida de Chironomus sancticaroli Strixino and Strixino, (Diptera, Chironomidae). Rev Bras Entomol 26: 183 189

Trivinho-STRIXINO S AND StriXINO G. 1989. Observations on the reproductive biology of a Neotropical chironomid (Diptera, Chironomidae). Rev Bras Biol 33: 207216.

Trivinho-Strixino S And Strixino G. 1995. Larvas de Chironomidae do Estado de São Paulo - Guia de identificação e diagnose dos gêneros. UFSCAR, p. 1-229.

WARD GM AND CUMMINS KW. 1979. Efffects of food quality on growth of a stream detritivore, Paratendipes albimanus (Meigen) (Diptera, Chironomidae). Ecology 60: $57-64$

Zilli Fl, Montalto L, Paggi AC and Marchese MR. 2008. Biometry and life cycle of Chironomus calligraphus Goeldi 1905 (Diptera Chironomidae) in laboratory conditions. Interciencia 33: 767-770. 